\title{
CORRESPONDENCE
}

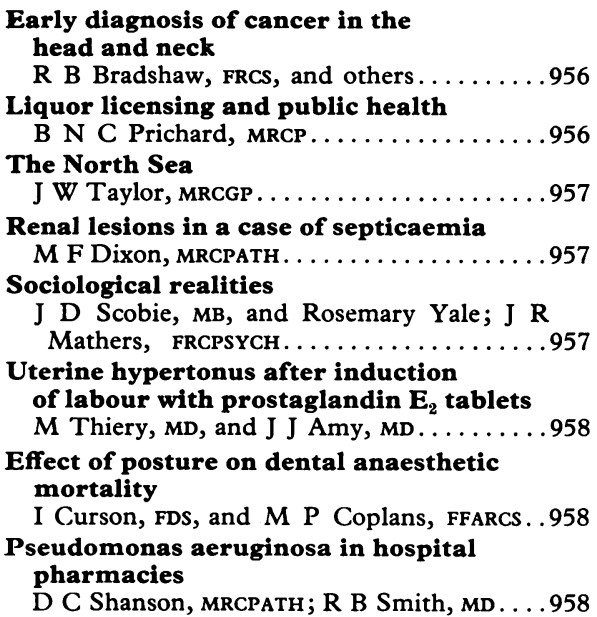

Supervision of repeat prescribing

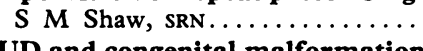

IUD and congenital malformatio

P C Leighton, FRCSED, and others . . . . . . . 959

Pets in hospitals

A J Macdonald, DPM; D MacCarthy, FRCP . 959

Shoplifting

M Segal, MRCPSYCH..............960

Osteomalacia and calcium deficiency

G F Taylor, MRCP..............960

Geriatrics in the cottage hospital

A $\mathbf{N}$ Crowther, BM................960

Domiciliary oxygen in chronic bronchitis

E L Head.......................960

Computer-held medical records

P R V Tomson, FRCGP; R McG Harden, MD,

and K A Harden, MB............960

Recurrent haematuria

P H O'Reilly, fRcs..............961

Propranolol and the nephrotic syndrome

M J Farr, MRCP.............. 961
Bottle-feeding and tummy-ache in infants

D L J Freed, мв. . . . . . . . . . . . .961 Amoebic meningoencephalitis in Britain

D C Warhurst, PHD, and others . . . . . . . 961 Squints

P A Gardiner, MD; A G Carroll, MRCPSYCH . 962 Occupational hazard in preparation of polyacrylamide gels

R A Klein, MB . . . . . . . . . . . . . . . . . .962

Steroids and hypostatic eczema

K Haeger, MD ............... 962

Occult perforations

B K Mandal, MRCPED, and P F Schofield,

FRCS .........................963

Specialist training

M D A Vickers, fFaRcs. . . . . . . . . .963

Future of private practice

C P Wallace, мв...............963

Compulsory vocational training

M H A Martin-Smith, MB, and others.....963

BMA and HCSA

N A Simmons, MRCPATH...........963
Correspondents are urged to write briefly so that readers may be offered as wide a selection of letters as possible. So many are being received that the omission of some is inevitable. Letters should be signed personally by all their authors.

\section{Early diagnosis of cancer in the head and neck}

SIR,-We heartily endorse the pleas of $\mathrm{Mr}$ H J Shaw (14 February, p 379) and Professor D F N Harrison (13 March, p 646) for a multi-disciplinary approach to head and neck tumours. However, we are concerned lest Professor Harrison's remarks lead your readers to believe that expertise is so scarce that most patients with head and neck cancer must travel great distances to obtain the treatment that will give them the best chance of cure.

Joint consultation clinics are held in nearly all teaching centres and in many non-teaching hospitals. Our clinic in Cardiff is a fairly typical example; the disciplines of otolaryngology, oral surgery, reconstructive surgery, and radiotherapy are represented. Jointly we see approximately 150 new patients with head and neck cancer annually. We do not practise "surgery by committee." The individual member of our group to whom the patient is

\section{Liquor licensing and public health}

SIR,-Anyone concerned with the limitation of the adverse effects of drugs can only view with misgiving the introduction of a private member's Bill to increase licensing hours and to allow children into public houses. Your timely leading article on the subject (14 February, p 359) must be applauded; I have already had occasion to sound a similar warning note. ${ }^{1}$

The principle that adverse effects to a given drug are proportional to its use and their increased availability leads to increased use (or abuse, or adverse reaction) is generally widely initially referred retains responsibility for that patient. He seeks the help and guidance of the other disciplines to decide upon and carry out an agreed policy. In this way confusion is avoided rather than created. Of the qualities Professor Harrison advocates, skill is subjective; but there is no evidence that in experience, equipment, or results, clinics such as ours are inferior to the more publicised centres.

Certainly the patient with head and neck cancer should be referred to a unit with special interest and experience. There is probably one near at hand.

R B BRADSHAW Michael Green

I P GRIFFITHS

J M HENK

$S$ H RICHARDS

University Hospital of Wales,

A B THOMAS

accepted. However, when ethyl alcohol is considered this seems less readily acknowledged. Is this justified as, assuming concern for the health and well-being of the public, supporters of the present Bill appear to believe ? It would seem that the onus is on those who wish to increase the availability of alcohol to prove that alcohol is an exception.

Evidence appears to be to the contrary. Firstly, there is much information showing that consumption of alcohol is correlated with the incidence of alcoholism. ${ }^{2-4}$ Secondly, it appears from "experi- ments" performed for a number of reasons that increase or decrease of alcohol consumption in the community causes the incidence of adverse effects to alcohol rise or fall. With the introduction of wine rationing in Paris in the last war annual mortality from cirrhosis of the liver fell rapidly from around 35 to 6 per 100000 , then quickly resumed its previous level at the end of rationing. ${ }^{3}$ Whatever the problems and failures of prohibition in the US, during that period the cirrhosis death rate fell from 11-15 to 7-8 per 100000 , only to resume its previous level after the end of prohibition. ${ }^{5} \operatorname{Dr} M \mathrm{M}$ Glatt (27 March, p 768) has again pointed out the effect of restricting licensing hours in the UK during the first world war in reducing alcoholism. ${ }^{6}$

Those who can believe that increasing drug availability, either through the number of outlets or the time that they are open, or teaching children to drink in the home will not lead to an increase in consumption should take a long, hard look at France. Here there is wide availability in hours, outlets, and cheapness and it is the cultural norm for children to be trained to drink in the home. France is top of the world in alcohol consumption and the alcoholism league, around 12 times the UK rate. ${ }^{7}$ Already there is recent suggestive evidence that increase in drug availability in the UK through supermarkets is having its first predictable effect-that is, increased acute toxicity, particularly among women.

I hope our legislators will read the recent WHO report $^{7}$ which concluded that it was time that measures were taken to reduce alcohol consumption-for instance, by elimination of mass media advertising. In view of the parlous state of the economy they perhaps ought to reflect on the cost of alcohol consumption to industrial production ${ }^{9}$ and the cost of alcohol-induced disease to the health services, said to be $40 \%$ of the total costs in France. ${ }^{7}$ With all the excitement about the drug bill to the NHS in some quarters it is pertinent to point out therefore that in some countries the cost of health problems induced by this one drug, alcohol, exceeds the cost of all drugs used for therapeutic purposes. Do our legislators wish to try to emulate this in 
the UK? In many countries the cost of alcohol-induced problems exceeds the revenue raised from alcohol taxation.

Let not anyone, even members of Parliament, be surprised that if you give more of drug you get a greater response. Whatever special aetiological factor-for example, genetic -there may be in alcoholism, this overall doseresponse relationship with alcohol and its effects on society are established with a high degree of probability. I do not think that the experiment that the legislators seemed poised to carry out would pass any hospital ethical committee; it's been done before and the risk of a high incidence of adverse effects is too great.

\section{University College Hospita Medical School, London WC}

Prichard, B N C, British fournal of Clinical Pharma cology, 1975, 2, 195

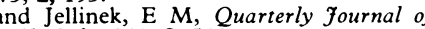
Studies on Alcohol, 1941, 2, 544.

Pequignot, G, and Cyrulnik, C, in International Encyclopaedia of Pharmacology and Therapeutics,
Section 20, ed J Tremolieres, vol 2, p 375. Oxford

' de Lint, J Proceedings of the First International Medical Conference of Alcoholism, $\mathrm{p} 75$. London, Edsell, Conferen
1975.

Klatskin, G, Gastroenterology, 1961, 41, 443.

Glatt, M M, British fournal of Addiction, 1958, 55, 5 . World Health Organisation, Expert Committee on Dru Dependence 20th Report. Geneva, WHO, 1974. Williams, P G, fournal of Alcoholism, 1975, 10, 122

"Murray, R M, Journal of Alcoholism, 1975, 10, 23.

\section{The North Sea}

SIR,-I read with interest your specia correspondent's article, "The North Sea" (20 March, p 705), and was impressed by the medical service operated by the eight general practitioners in Yarmouth. In the north-east of Scotland we have a similar set-up, which operates under the aegis of the Institute of Environmental Medicine of Aberdeen University. Unfortunately the institute is not yet as fully operational as it might be and there are still some individual arrangements being made, which tends to fragment and incoordinate medical care. This on occasion leads to duplication of effort and possibly variation in standards.

The NHS does not yet recognise a responsibility below the low-water line, but a recent court decision in Scotland (Crown Estates $v$ Fairlie Boatyard) may help to change this situation. One of the problems of treating personnel on rigs and barges is the question of insurance, both accident and medicolegal, of doctors who supply services to off-shore installations, and this might be eased if the NHS were to become responsible for off-shore medical care, as indeed do police forces in their own fields.

I would agree that a national system of monitoring the health of divers should be instituted, especially as the number of divers is relatively small, and I hope that Admiral Rawlins's committee will take up this point. Funds should be made available, preferably from Government sources, for research into the long-term effects of compression, which would include hyperbaric facilities, computersation, etc. A national register of divers is a must, as it is not unknown that a diver who has failed a medical with one company seeks to be employed by another company and may conceal relevant medical history.

In the article divers are described as "mavericks" and elsewhere as "prima donnas," but I feel that it should be the diver's own responsibility to ensure that his medical checks are up to date and that he holds valid certificate of medical fitness. This responsibility already applies in the case of commercial airline pilots and heavy goods vehicle drivers. The medical records of the former are held and scrutinised centrally, and it takes the examining doctor only a few minutes by telephone to get a full breakdown on past medical history when required.

In the article it is stated that necropsies revealed some degree of right ventricular hypertrophy in otherwise healthy men. An impression I obtained, admittedly from the records of a small number of divers, was that the diastolic pressure was over $80 \mathrm{~mm} \mathrm{Hg}$ more frequently than I would have expected in a similar number of men in the 20-35-year age group.

The profession should seize this opportunity of serving and investigating this new field of off-shore medicine.

\section{Dyce,
Aberdeen}

J W TAYLOR

\section{Renal lesions in a case of septicaemia}

SIR,-In replying to the criticisms of Wing Commander $\mathrm{T} J$ Betteridge and Squadron Leader D J Rainford (28 February, p 522) I should like to make two preliminary points. Firstly, as many readers will be aware, the published accounts of clinicopathological conferences are edited versions of the proceedings. Some descriptive details are inevitably omitted, while the original presentation itself has to be a concise, didactic account of the pathological findings. Secondly, although histological diagnosis is a matter of subjective interpretation, our opinion is based on the examination of numerous tissue sections and not on two photographs.

The glomerular changes in the case presented were not focal. There was a diffuse increase in cellularity affecting all glomeruli apart from those hyalinised by previous ischaemic damage. While minor variations in the degree of hypercellularity were noted, there was little or no tendency for local or segmental variation within individual glomeruli. A measure of the degree of proliferation is given by total glomerular cell counts. The cells (excluding leucocytes) present in 20 midline sections of glomeruli in $1-\mu \mathrm{m}$ sections stained by the periodic acid-Schiff method were counted. The mean cell count $( \pm 1$ SD) was $194+18$, which compares with a normal count of 122 for adul females. ${ }^{1}$ The hypercellularity was principally a result of endothelial cell proliferation, but there was a definite increase in mesangial cells. Neutrophil polymorphs were present in excessive numbers throughout the glomeruli. Fibrin thrombi and foci of necrosis were not seen.

A diffuse, mild to moderate increase in mesangial matrix and a slight irregular thickening of tuft loops were present. While electron microscopy did not reveal convincing sub-epithelial "humps," it did confirm the presence of finely granular, electron-dense deposits of matrix or basemen membrane-like material in the mesangium. It is unfortunate that tissue was not retained for immunofluorescence studies, but this deficiency does not preclude an accurate diagnosis; indeed, the results obtained from necropsy material may well be unsatisfactory.

Our diagnosis of diffuse proliferative glomerulonephritis in a patient with staphylococcal septicaemia and acute bacterial endocarditis of short duration is not "most unusual." Powell found this form of glomerulonephritis in 16 of 40 patients dying from staphylococcal septicaemia, ${ }^{2}$ and its association with coagulasenegative staphylococcal bacteriaemia complicating the insertion of ventriculoatria shunts for hydrocephalus has been clearly established. ${ }^{3-5}$

Most authorities recognise two forms of glomerulonephritis in bacterial endocarditis. Firstly, a focal type ("embolic" nephritis) characterised by segmental fibrinoid necrosis with local proliferation of cells infrequently associated with impaired renal function; and secondly, a diffuse proliferative lesion, in which elevation of blood urea nitrogen and creatinine levels is common. Heptinstal claims that the focal form is very uncommon in cases of short duration irrespective of the organism. ${ }^{6}$ Diffuse proliferative glomerulonephritis complicating coagulase-positive staphylococcal endocarditis has been well documented $^{6-8}$ and has been substantiated by animal experiments. ${ }^{9}$

At a clinicopathological conference published in $1960^{10}$ a 52-year-old man was presented who developed staphylococcal septicaemia following a laminectomy and died in renal failure. Post-mortem examination revealed acute bacterial endocarditis involving the tricuspid valve and a diffuse proliferative glomerulonephritis. Our case represents a further example of this interesting but not infrequent complication.

M F DIXON

University Department of Pathology,

School of Medicine,

Leeds

Sheehan, H L, and Lynch, J B, Pathology of Toxaemia f Pregnancy, $\mathrm{p} 51$. Edinburgh, Churchill Livingstone, 1973 .

Powell, D F B, fournal of Pathology and Bacteriology,

1961, 82, 141. Lancet, 1965, 2, 921.

tickler, G B, et al, New England fournal of Medicine, 1968, 279, 1077.

Association, 1970, fournal of

Heptinstall, R H, Pathology of the Kidney, 2nd edn vol 1, p 461. Boston, Little, Brown, 1974 .

Tu, W H, Shearn, M A, and Lee, J C, Annals of Internal Medicine, 1969, 71, 335 .

Gutman, R A, et al, Medicine, 1972, 51, 1 .
Highman, B, Altland, P D, and Roshe, J, Circulation Research, 1959, 7, 982 .
ighman, B, Altland,

Clinicopathologic Conference, American fournal of Medicine, 1960, 28, 430.

\section{Sociological realities}

SIR,-In your leading article under this heading (3 April, p 790) you ask, "Why then is so little being done to halt the decay and decline of the links between the health and social services ?" At a recent half-day meeting in this division between social workers and general practitioners it was striking that there was a much more positive wish to do this among the former than among the latter. It came over strongly that mutual expectations were in conflict and sometimes unreal. The GPs felt that the ideal social worker should be more active and of practical help (like GPs) and the social workers felt the ideal GP should find time to be understanding, tolerant, and willing to listen (characteristics which they value highly in themselves).

This contrast in attitudes is borne out in your article, which fails to recognize the complexity of the roles of the social services in the community. These roles are still in the process of definition, and if doctors wish to enter the debate they will have to find time to sit around and discuss with social workers their differing roles and attitudes as well as the practicalities 